\title{
REPRESENTASI BRAND ISLAMI DALAM PRODUK KOPI (ANALISIS SEMIOTIKA ROLAND BARTHES PADA BRAND PRODUK KOPI)
}

\author{
Ari Susanti, Nabila Alifiana Firdausi \\ Program Studi Ilmu Komunikasi Universitas Muhammadiyah Jember \\ Email :ari.susanti@unmuhjember.ac.id ; nabilaalifiana@gmail.com
}

\begin{abstract}
Brand is the important thing in the process of buying a product. The majority of the Indonesia population is Muslim. Many products in the market are doubtful about the level of halalness. This study examines the representation of Islamic brands of coffee products to influence purchasing decisions. Although many factors influence purchasing decisions such as price and taste, the focus of research remains on Islamic brands. This study is entitled Representation of Islamic Brands in Coffee Products - Roland Barthes's Semiotic Analysis of Coffee Product Brands Sakinah. The Semiotic Roland Barthes approach which is the basis of the analysis of this research is because many cultural elements will be involved. This qualitative research approach with analytical triangulation techniques which are data triangulation, method triangulation and theory triangulation. The results of this study are Islamic brands be easily accepted by the Indonesian market, which is predominantly Muslim. By using Islamic brands that have an impact on consumer confidence in the halalness of the product. In addition, using familiar words such as Sakinah will speed up the process of receiving products in the community. Thus, it will be easily to promoting products in the Indonesia because Islamic brands similar with halal food.
\end{abstract}

\section{Keywords : Semiotic Analysis, Brands, Islamic}

\begin{abstract}
Abstrak
Brand atau merek merupakan hal yang menentukan dalam proses pembelian suatu produk. Mayoritas penduduk Indonesia adalah beragama Islam. Banyak produk yang beredar di pasar yang disangsikan tingkat kehalalannya. Penelitian ini mengupas representasi brand Islami produk kopi dalam keputusan pembelian. Meskipun banyak faktor yang mempengaruhi keputusan membeli seperti harga dan rasa, fokus penelitian pada brand islami yaitu kopi Sakinah dimana sebelumnya memiliki brand kopi Leonna dari yang berasal Kabupaten Bondowoso sebagai industri kecil rumah tangga yang dikelola secara tradisional.

Penelitian ini berjudul Representasi Brand Islami dalam Produk Kopi - Analisis Semiotika Roland Barthes pada Brand Produk Kopi. Pendekatan Semiotika Umberto Eco yang menjadi pijakan analisis penelitian ini dikarenakan unsur budaya akan banyak akan diteliti dengan pendekatan penelitian deskriptif kualitatif. Adapun teknik pengambilan data dilakukan dengan teknik wawancara mendalam, observasi secara berkala disertai dokumentasi. Hasil penelitian ini adalah penggunaan brand yang bernuansa Islami akan mudah diterima oleh pasar Indonesia yang mayoritas beragama Islam. Dengan
\end{abstract}


menggunakan brand yang islami berdampak pada keyakinan konsumen atas kehalalan produk tersebut. Selain itu, menggunakan kata yang familiar seperti Sakinah akan mempercepat proses penerimaan produk di masyarakat. Dengan demikian, akan mempermudah kerja pemasaran dalam mempromosikan produk-produk dengan brand Islami identik dengan produk-produk yang halal.

\section{Kata kunci : Analisis Semiotika, Brand, dan Islami}

\section{Pendahuluan}

Kopi adalah produk pangan rakyat. Kopi adalah minuman seduhan yang terbuat dari biji kopi yang telah mengalami proses disangrai kemudian dihaluskan hingga menjadi bubuk. Secara tradisional, kopi disajikan dengan air mendidih dalam cangkir dengan gula sesuai selera. Di Indonesia, tanaman kopi tumbuh dengan subur. Pada masa penjajahan, Belanda menjadikan Indonesia sebagai produsen kopi terbesar dunia. Sebagai minuman bangsa-bangsa seluruh dunia, kopi adalah menjadi produk yang tidak pernah sepi diburu pembeli.

Pegunungan Ijen Raung Bondowoso adalah salah satu daerah yang cocok untuk ditanami kopi. Produk kopi Kabupaten Bondowoso ini tidak kalah bersaing dengan produk kopi dari daerah lainnya. Pepatah mengatakan, "Lain ladang lain belalang". Kopi pun demikian, dengan perbedaan struktur tanah, cuaca dan curah hujan akan menghasilkan rasa kopi yang berbeda meskipun dengan varietas kopi yang sama. Oleh karenanya, Bondowoso memiliki slogan "Bondowoso Republik Kopi (BRK)" dimana kopi Bondowoso layak disejajarkan dengan kopi-kopi dari daerah lain seperti kopi Gayo Aceh, kopi Toraja, kopi Bali dan lain-lain. Namun demikian, kopi bukanlah produk unggulan Kabupaten Bondowoso. Bondowoso lebih dikenal dengan kota tape ketimbang kota kopi.

Salah satu produsen kopi asli Bondowoso adalah kopi Pondok Leonna. Produk kopi Pondok Leonna adalah kopi robusta yang diolah secara tradisional dengan metode sangrai dan ditumbuk. Berdasarkan wawancara dengan pemilik kopi Pondok Leonna yaitu Christian Agung, kopi Bondowoso lemah dalam hal pemasaran. Selain itu, peran Pemerintah Daerah dalam mempromosikan produk kopi unggulan Bondowoso belum maksimal.

Untuk mensiasati pemasaran, kopi Pondok Leonna melakukan mengeluarkan produk kopi baru dengan brand SAKINAH. 
Kopi Sakinah dan kopi Pondok Leonna adalah produk yang sama, yang dikemas ulang. Dalam waktu 2 bulan, kopi Sakinah telah diproduksi sebanyak $40 \mathrm{~kg}$ sedangkan kopi Pondok Leonna tetap terjual di bawah angka $5 \mathrm{~kg}$. Produksi kopi Pondok Leonna bertahan diangka di bawah $5 \mathrm{~kg}$ per bulan selama kurun waktu 5 tahun terakhir. Kehadiran Kopi Sakinah mendominasi produk kopi Pondok Leonna.

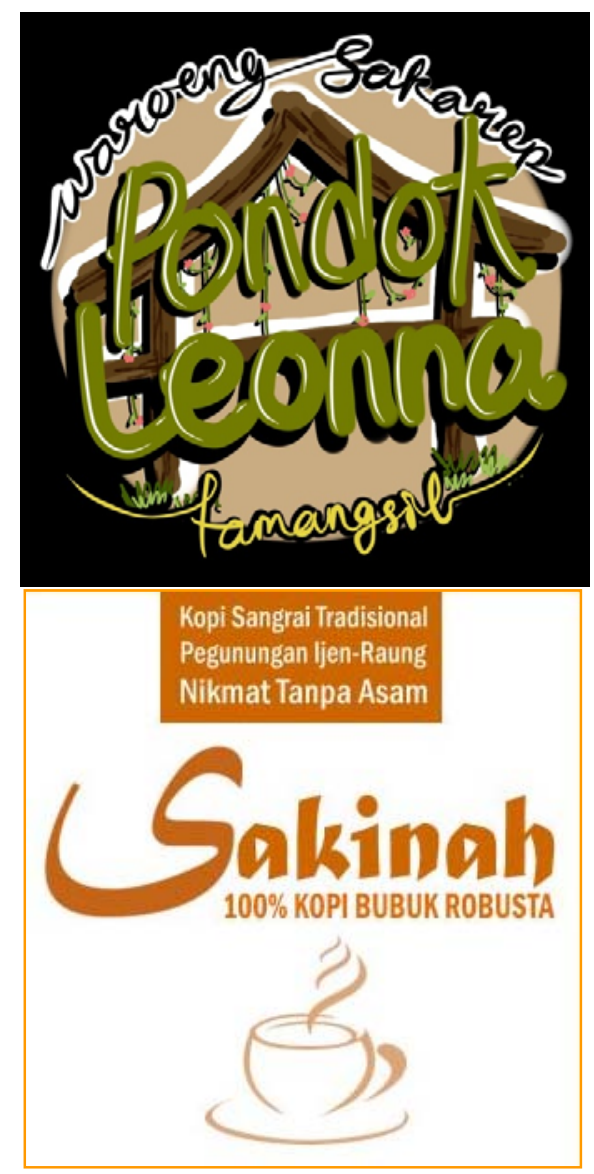

Gambar 1 : Perbandingan Brand Kopi Pondok Leonna dan Kopi Sakinah
Hal menarik yang perlu dikaji lebih lanjut adalah metamorfosa nama Pondok Leonna menjadi Sakinah. Dari perspektif linguistik, Pondok Leonna berasal dari bahasa Indonesia baku yang terdiri dari kata pondok dan Leonna. Pondok adalah sebuah rumah, bangunan atau tempat berteduh, sedangkan Leonna adalah nama seorang wanita. Dengan demikian, Pondok Leonna adalah pondok milik Leonna. Bertolak belakang dengan Sakinah yang berasal dari bahasa Arab yang artinya kedamaian, tenang, tentram dan aman.

Sektor industri makanan selalu dinamis. Brand baru muncul bukan hal aneh. Persaingan produk sejenis tidak hanya dalam hal perang harga dan rasa, tetapi juga perang dalam hal brand, kemasan dan posisioning produk. Hal ini juga terjadi pada Kopi Pondok Leonna dan Kopi Sakinah. Dalam tempo 2 bulan setelah diluncurkan, kopi Sakinah mampu beradaptasi dengan masyarakat.

Penelitian sejenis mengenai analisis rebrand maupun pergantian masih jarang dilakukan. Adapun penelitian terdahulu lebih banyak menganalisis merek atau brand yang sudah ada di pasar seperti karya Murti Candra Dewi selaku alumni Prodi Ilmu Komunikasi Universitas Islam Negeri 
MEDIAKOM : Jurnal IImu Komunikasi Vol. 03 No. 01 Tahun 2019

p ISSN : 2580-1899 | e ISSN : 2656-5706

Sunan Kalijaga Yogyakarta dalam judul

"Representasi Pakaian Muslimah dalam

Iklan (Analisis Semiotika Charles Sanders Peirce pada Iklan Kosmetik Wardah di Tabloid Nova)". Hasil yang diperoleh dalam penelitian tersebut adalah "busana muslim dalam iklan Wardah Cosmetics diwakili melalui penggunaan busana yang menutupi aurat namun tetap stylish dan fashionable, sehingga memperkuat citra Islam modern yang dibangun oleh Wardah.” (sumber : http://ejournal.uin-

suka.ac.id/isoshum/profetik/article/view/11

$\underline{71}$ - diunduh pada tanggal 12 Februari 2019)

Penelitian lain yang menjadi referensi penelitian diambil karya M. Alhafis Wijaya Putra selaku mahasiswa Universitas Islam Indonesia Yogyaarta dengan judul penelitian "Representasi Pakaian Sebagai Identitas Anak Muda (Analisis Semiotika pada Merek Dreambirds Artwear). Hasil penelitian ini bahwa "mitos Dreambirds Artwear sendiri menggambarkan tentang remaja yang ingin tampil beda, karismatik, bijaksana yang tidak hanya tampil dengan fashion yang terlihat hebat. Dreambirds Artwear mengangkat nilai-nilai tentang keinginan remaja, sehingga kaum muda tertarik dengan konsep tersebut." (Sumber : https://dspace.uii.ac.id/handle/123456789/4 $\underline{102}$ - diunduh pada tanggal 12 Februari 2019). Penelitian ini lebih merujuk bagaimana brand dikreasi sedemikian rupa sehingga merek dapat membangun citra brand sesuai dengan yang diharapkan.

Penelitian yang akan dilakukan peneliti akan berfokus pada pergantian merek dan pemilihan merek atau brand baru dengan memadukan berbagai kajian dengan menggunakan pendekatan analisis semiotika. Berdasarkan uraian di atas dapat disimpulkan permasalahan mendasar dalam penelitian ini adalah bagaimana representasi brand islami dalam produk kopi Sakinah.

\section{Tinjauan Pustaka}

\section{Analisis Semiotika}

Alex Sobur mendefinisikan semiotika sebagai suatu ilmu atau metode analisis untuk mengkaji tanda. Tanda-tanda adalah perangkat yang kita pakai dalam upaya berusaha mencari jalan di dunia ini, di tengah-tengah manusia dan bersama-sama manusia. Semiotika - atau dalam istilah Barthes, semiologi—pada dasarnya hendak mempelajari bagaimana kemanusiaan (humanity) memaknai hal-hal (things). Memaknai (to signify) dalam hal ini tidak 
MEDIAKOM : Jurnal IImu Komunikasi Vol. 03 No. 01 Tahun 2019

p ISSN : 2580-1899 | e ISSN : 2656-5706

dapat dicampuradukkan dengan Mitos adalah produk kelas sosial yang

mengkomunikasikan (to communicate). sudah mempunyai suatu dominasi."

Memaknai berarti bahwa objek-objek tidak

Brand atau Merek

hanya membawa informasi, tetapi juga

Definisi Brand atau Merek

mengkonstitusi sistem terstruktur dari tanda.

Roland Barthes (1915-1980)

menggunakan teori siginifiant-signifié dan

muncul dengan teori mengenai konotasi.

Konotasi memiliki makna yang subjektif atau paling tidak intersubjektif. Denotasi adalah apa yang digambarkan tanda terhadap objek, sedangkan konotasi adalah bagaimana cara menggambarkannya. Perbedaan pokoknya adalah Barthes menekankan makna konotasi yang muncul secara subjektif sehingga kehadirannya tidak disadari. Hal yang paling menonjol pada semiotika Barthes adalah mitos.

Dalam kerangka Barthes, konotasi identik dengan operasi ideology, disebut dengan mitos, dan berfungsi untuk mengungkapkan dan memberikan pembenaran bagi nila-nilai dominan yang berlaku dalan suatu periode tertentu (Sobur, 2006; 71). Menurut John Fiske (1990; 88), "mitos adalah bagaimana kebudayaan menjelaskan atau memahami beberapa aspek tentang realitas atau gejala alam.

Menurut Kottler dan Gary, dalam Manap (2016, 264) istilah brand didefinisikan sebagai berikut :

"A brandin is a name, term, sign, symbol or desing or a combination of these, intended to identify the goods or service of one seller or group and to differenciate them from those competitors. (Brand adalah sebuah nama, istilah, tanda, simbol atau desain, atau kombinasinya yang bertujuan untuk mengidentifikasi barang dan jasa yang membedakan suatu produk dengan produk pesaing."

Dari definisi yang disampaikan Kottler dan Gary, brand sebagai nama atau identitas yang membedakan antar produk sejenis yang ada di pasar. Hal senada juga disampaikan oleh Cravens bahwa "suatu citra merek yang kuat memberikan beberapa keunggulan utama bagi suatu perusahaan. nama merek yang membedakan suatu produk dari-produk-produk pesaing. Sebuah identitas merek yang kuat menciptakan suatu keunggulan bersaing utama." $(1994,17)$ 
MEDIAKOM : Jurnal IImu Komunikasi Vol. 03 No. 01 Tahun 2019

p ISSN : 2580-1899 | e ISSN : 2656-5706

\section{Tujuan Pemberian Brand atau Merek}

Pemberian brand atau merek memiliki tujuan. Tujuan dari pemberian merek ini ada berbagai macam. Adakalanya, merek memiliki beberapa tujuan sekaligus. Menurut Manap (2016; 265-266), tujuan dari pemberian brand atau merek adalah sebagai berikut:

1). Pengusaha menjamin konsumen bahwa barang yang dibeli sungguh berasal dari perusahaannya. Ini adalah untuk menyakinkan pihak konsumen membeli sesuatu barang dari merek dan perusahaan yang dikehendakinya, yang cocok dengan seleranya, keinginannya dan kemampuannya.

2). Perusahaan menjamin mutu barang. Dengan adanya merek ini perusahaan menjamin mutu barang yang dikeluarkannya berkualitas baik sehingga dalam barang tersebut selain ada merekmerek juga disebut peringatan-peringatan.

3). Pengusaha memberi nama pada merek barangnya supaya mudah diingat dan disebut sehingga konsumen dapat menyebut mereknya saja.

4). Meningkatkan ekuitas merek yang memungkinkan memperoleh margin lebih tinggi, memberi kemudahan dalam mempertahankan kesetiaan konsumen
5). Memberi motivasi pada saluran distribusi karena barang dengan merek terkenal akan cepat laku dan mudah disalurkan.

\section{Syarat-syarat Memilih Brand atau}

Merek

Brand atau merek adalah identitas diri dari sebuah produk. Identitas diri sama halnya dengan nama. Perlu dipertimbangkan dengan matang dalam memberikan nama pada produk karena nama akan selalu melekat selama produk tersebut ada. Nama juga selalu disebut dalam setiap kesempatan. Oleh karena itu, ada beberapa syarat yang perlu diperhatikan dalam memilih brand, antara lain :

1). Mudah diingat. Dengan cara mencari kata yang sederhana, mudah diucapkan, kata yang sering digunakan namun memiliki makna sesuai dengan tujuan pemberian brand atau merek.

\section{2). Menimbulkan kesan positif.}

Pemilihan brand hendaknya memberikan kesan positif pada produk. Seperti halnya nama, merek adalah doa dan harapan dari pemilik produk. Karenanya, merek yang memiliki kesan positif akan memudahkan pengambilan keputusan pembelian.

3). Tepat untuk promosi. Hendaknya brand atau merek yang dipilih memiliki 
nilai jual dengan melihat perkembangan pasar dan keinginan konsumen pada umumnya. Dengan memperhatikan pasar dan konsumen maka akan memudahkan promosi.

\section{Brand Genius}

Dalam menentukan brand, perlu diperhatikan formula brand genius. Brand genius ini mengupas esensi brand dan merek dalam 3 aspek (Manap, 2016 ; 275276). Pertama adalah unique (unik). Merek harus memiliki keunikan. Keunikan yang dimaksud adalah keunggulan dari produk atau jasa yang ditawarkan yang berbeda dengan produk sejenis lainnya baik berupa kualitas produk, kuantitas produk, ciri khas produk, dan masih banyak yang lain. Dengan keunikan ini, maka akan melekat dalam ingatkan konsumen.

Kedua adalah emotion. Merek akan dicintai bila memiliki hubungan emosi yang kuat dengan konsumennya. Emosi bisa berupa rasa senang, sedih, cinta, bangga, marah, dan lain-lain. Tentunya, untuk membangkitkan emosi tersebut, panca indera berperan penting. Misalnya dilihat dari sisi bentuk dan warna dapat menggairahkan rasa.

Ketiga adalah creative. Merek yang kreatif akan dipuja oleh pelanggannya dan terus menciptakan keunggulan baru. Kreativitas akan merangsang inovasi yang mampu membuahkan keunikan-keunikan yang merevolusi pemasaran. Sehingga pelanggan akan terus penasaran dan terus melakukan pembelian. Berikut gambar tentang konsep brand genius :

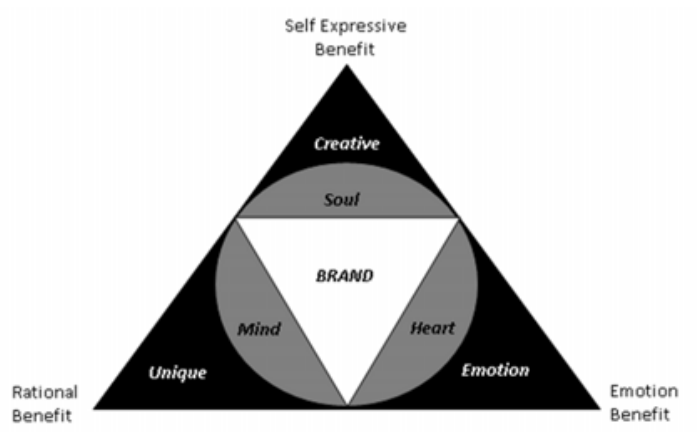

Gambar 3: Brand Genius (Sumber : Manap, 2016 ; 276)

\section{Islami}

Islami diambil dari kata Islam dimana Islam adalah agama yang diajarkan oleh Nabi Muhammad SAW. Islami yang dimaksud dalam penelitian ini memiliki arti sebagai cara-cara atau hal-hal yang sesuai dengan ajaran Islam. Pada hakekatnya, Islami adalah atribut yang melekat pada entitas sosial atau individual yang menjalankan ajaran Nabi Muhammad SAW, meskipun tidak secara eksplisit menyatakan diri sebagai Islam. 
Lalu, apakah islami itu ? Islami adalah adalah seperangkat nilai-nilai yang berupa perilaku, suasana, lambang, hukum yang memenuhi syariat-syariat Islam. Syariat yang dimaksud adalah pedoman ajaran Islam berpegang teguh pada Al Quran dan Hadist. Islami mencerminkan setiap perilaku, suasana, lambang, hukum yang memenuhi syariat Islam.

Hal menarik yang telah dilakukan oleh Hossein Askari dan Scheherazade S. Rehman, dua peneliti dari The George Washington University, melakukan penelitian tentang negara-negara yang paling islami dan menyimpulkan bahwa "Yang Islami tidak selalu Islam, sementara yang Islam belum tentu Islami." Hal ini dikarenakan negara yang memiliki indeks Islamic tertinggi adalah New Zeland dimana di setiap aktivitas penduduknya mencerminkan nilai-nilai Islam.

\section{Metode Penelitian}

\section{Jenis Penelitian}

Penelitian ini merupakan penelitian deskriptif kualitatif. Jenis penelitian deskriptif bertujuan menjabarkan secara sistematis, factual dan akurat tentang faktafakta dan sifat-sifat objek penelitian. Sedangan penelitian kualitatif merupakan jenis penelitian yang memberikan kesempatan seluas-luasnya kepada peneliti untuk mengalih data sebanyak-banyaknya sehingga diperoleh data yang lebih mendalam dan komprehensif. Dengan demikian penelitian deskriptif kualitatif berusaha menjabarkan secara sistematis, factual dan akurat mengenai data-data yang dapat dipertanggung jawabkan dengan terperinci dan komprehensif selama proses penelitian.

\section{Unit Analisis}

Penelitian ini berfokus pada brand produk kopi yang dikeluarkan oleh UD Keristal Taru Bumi di Pondok Leonna Dusun Tamangsil Kecamatan Wonosari Kabupaten Bondowoso. Oleh karena itu, unit analisis adalah merek kopi "Pondok Leonna" dan "Sakinah" yang akan dikaji menggunakan pendekatan analisis semiotika.

\section{Teknik Pengumpulan Data}

Dalam mengumpulkan data, peneliti menggunakan beberapa teknik sebagai berikut :

Wawancara mendalam / in dept interview. Wawancara dilakukan untuk memperoleh data primer sebanyakbanyaknya dengan mengambil dua orang informan, yaitu UD Keristal Taru Bumi di Pondok Leonna Dusun Tamangsil 
MEDIAKOM : Jurnal IImu Komunikasi Vol. 03 No. 01 Tahun 2019

p ISSN : 2580-1899 | e ISSN : 2656-5706

Kecamatan Wonosari Kabupaten kopi mulai menyebar ke negara Turki,

Bondowoso.

nama "qahwah" diadaptasi dengan istilah

Observasi. Kunjungan dilakukan untuk "kafveh". Setelah memasuki wilayah Eropa, melihat lebih dekat operasionalisasi UD

Keristal Taru Bumi di Pondok Leonna

Dusun Tamangsil Kecamatan Wonosari Kabupaten Bondowoso

Foto dokumentasi sebagai dokumen penunjang kelengkapan penelitian.

\section{Hasil Penelitian}

\section{Analisis Semantik Semiotika}

Pada pembahasan ini akan dikaji secara mendalam tentang makna dari brand baru kopi Sakinah dari pemilihan nama atau brand. Pemilihan nama brand produk makanan dan minuman dengan menggunakan bahasa Arab. Bahasa Arab identik dengan Islam. Apabila ditarik benang merahnya bahwa pemilihan brand Sakinah ini bertujuan untuk menguatkan kesan dan pesan bahwa kopi tersebut diproduksi secara islami. Islami yang dimaksud adalah kopi tersebut diproses secara halal atau dibenarkan menurut syariat Islam.

Istilah kopi yang dikenal saat ini, berasal dari bahasa resapan Arab قهوة (dibaca qahwah) berarti kekuatan. Hal ini karena pada mulanya kopi ditemukan sebagai makanan berenergi tinggi. Setelah

kata "kavfeh" diadopsi lagi dengan istilah "coffee" hingga saat ini.

Kopi memiliki sejarah penting bagi bangsa Arab. Biji kopi memang ditemukan di Afrika pada 1000 SM di Afrika Timur. Namun baru sekitar abad ke-7, bangsa Arab yaitu Yaman mulai mengenal kopi sebagai minuman berenergi yang mampu untuk suplemen begadang. Sejalan dengan penyebaran agama Islam di wilayah Arab, kopi dikonsumsi untuk tetap terjaga di malam hari sehingga bisa melakukan ibadah malam hari baik sholat malam, tadarus hingga berzikir. Karena itu, banyak umat Islam yang mengkonsumsi kopi untuk tujuan ibadah.

Dengan demikian, memberikan label kopi Sakinah memiliki makna yang dalam. Brand kopi Sakinah yang berarti kedamaian, tenang, tentram, dan aman memiliki arti yang selaras dengan sejarah perkembangan kopi dengan penyebaran agama Islam. Kopi dikonsumsi untuk menambah kekhusyukan dalam beribadah kala itu untuk memberikan kedamaian, rasa tenang, tentram dan aman bagi umatnya. Seiring perkembangan jaman, kopi pun 
juga tetap memberikan banyak banyak makna lain misalnya memberikan inspirasi, tetap focus dalam melakukan sesuatu, hingga candu dimana hari terasa tidak lengkap jika tidak minum kopi hari ini.

\section{Brand Dan Masyarakat}

Brand yang berhasil adalah brand yang kuat tertanam di benak masyarakat selaku konsumen produk kita. Dalam memilih brand yang tepat dan kuat menurut Manap (2016 ; 275-276), harus memperhatikan ada tiga hal utama yaitu :

Self Expressive Benefit, dimana brand harus mengandung unsur kreatif. Kreatif akan berdampak pada keterbukaan terhadap segala hal hingga mudah untuk merefleksikan diri tentang produk. Tanpa banyak berpikir, produk sudah sesuai dengan yang diharapkan oleh konsumen.

\section{Pada brand}

Sakinah penggunaan huruf memadukan font yang menarik yaitu huruf hijaiyah dan huruf $ي$. Sebagai pengganti huruf " $S$ " menggunakan huruf (dibaca $y a k$ ) dipadukan dengan font Matura MT Script Capitals memberikan kesan elegan. Penggunan warna huruf coklat merepresntasikan warna bubuk kopi yang segar dan wangi.

Rational Benefit, dimana brand harus mengandung unsur unik. Unik yang dimaksud adalah yang mudah diingat bisa karena langka atau bahkan sangat sederhana. Sehingga keunikan ini akan tertanam dibenak konsumen dengan mudah dan bertahan lama. Kata Sakinah sering disebutkan ketika kita memberikan ucapan selamat menempuh hidup baru kepada pasangan yang baru menikah dengan harapan semoga pernikahan langgeng dan damai. Selain itu, kata Sakinah juga sering digunakan sebagai nama anak terutama anak perempuan dengan harapan anak tersebut membawa kedamaian dan ketentraman dalam keluarga. Kata Sakinah sudah familiar di benak masyarakat sehingga mudah dingat dan memiliki makna yang dalam.

Emotion Benefit, dimana brand merepresentasikan ekspresi yang ingin dicapai dalam produk yang dimaksud. Misalnya rasa pedas diekspresikan dengan kata "Huh Hah" yang berusaha merepresentasikan rasa pedas pada brandnya. Sehingga konsumen dapat merasakan sensasi pedas sesuai yang diharapkan. Dilihat dari penggunaan brand Sakinah yang memiliki arti kedamaian, tentram, tenang dan aman. Pemberian brand Sakinah ini diharapkan kopi Sakinah membawa rasa khusyuk seperti halnya 
anjuran umat Islam terdahulu untuk meminum kopi dengan tujuan menambah kekhusyukan beribadah di malam hari.

Brand dan masyarakat saling terkait. Kesuksesan brand ditentukan dari budaya dan keyakinan masyarakat. Masyarakat yang mampu merasakan produk hanya dari brand yang ditampilkan menjadi faktor penting dalam keberhasilan dari kelangsungan produk tersebut. Pada brand Sakinah ini, diusahakan masyarakat merasakan kedamaian dan tentram. Di samping itu, memilih kata yang familiar juga menjadi penentu sehingga konsumen merasakan kenyamanan karena sudah akrab disebutkan dan didengarkan. Brand Sakinah yang diadopsi dari bahasa Arab memiliki pesan yang kuat bahwa kopi yang diproduksi tersebut aman dan halal untuk dikonsumsi. Sehingga masyarakat tidak ragu untuk membeli produk tersebut.

\section{Brand Pangan Islami}

Kehalalan pangan yang tercermin dalam brand Sakinah membuat masyarakat tidak ragu memilih produk tersebut. Sakinah yang diadopsi dari bahasa Arab bermakna garansi atau jaminan bahwa produk tersebut halal untuk dikonsumsi sesuai syariat islam. Dalam ajaran Islam, halal meliputi minimal 3 aspek, meliputi :
Halal secara zatnya. Seperti yang telah dijelaskan di atas bahwa kopi adalah minuman yang dianjurkan untuk dikonsumsi untuk tujuan yang baik seperti menambah kekhusyukan beribadah, memberikan inspirasi dan membuat tetap fokus. Tentu saja, Islam menganjurkan agar tidak berlebihan dalam banyak hal. Makan berlebihan tidak dianjurkan karena akan menyakiti pencernaan, dalam minum kopi pun sama. Bukan berarti kopi menjadi minuman yang dianjurkan Rasullullah serta merta meminum kopi berlebihan. Meminum kopi berlebihan juga tidak baik untuk kesehatan.

Kopi memang halal secara zatnya meski demikian tetap dikonsumsi dalam batas yang sewajarnya. Seperti yang sudah dicantumkan dalam Al Quran surat Al Baqarah ayat 168 yang artinya "Hai Manusia, makanlah dari apa yang terdapat di bumi, yang halal dan yang thoyyib. Dan janganlah kamu menuruti jejak setan (yang suka melanggar atau melampaui batas). Sesungguhnya setan itu adalah musuh kamu yang nyata."

Halal cara memprosesnya. Membahas proses pembuatan kopi sebagai minuman, terlebih dahulu akan dijelaskan bagaimana proses pengolahannya. Ada dua proses 
penting dalam pengolahan kopi yang siap saji yaitu proses pengolahan hulu dan proses pengolah hilir.

Proses pengolahan hulu diawal dari panen buah kopi yang dilakukan secara manual yaitu memetik buah kopi yang siap panen. Buah kopi yang siap panen ditandai dengan perubahan warna kulit kopi dari warna hijau tua ketika muda, berwarna kuning ketika setengah masak, merah ketika matang dan hitam jika terlalu masak. Sebaiknya memanen buah kopi yang berwarna merah. Selanjutnya dilanjutkan proses sortasi yaitu pemilihan buah kopi berdasarkan warna kemasakannya bahkan memisahkan dengan buah kopi yang rusak. Proses berikutnya adalah pengelupasan kulit kopi dan dilanjutkan dengan proses fermentasi. Fermentasi dilakukan guna menghilangkan lender yang melekat pada biji kopi dimana lendir tersebut membawa rasa pahit pada kopi. Setelah itu dilakukan pencucian dan pengeringan. Proses pengeringan dilakukan secara alamiah yaitu dijemur. Setelah kering maka dilakukan pengelupasan kulit kopi, sehingga kopi yang berkualitas benar-benar diambil dari biji kopi pilihan dengan proses pengolahan yang panjang.
Proses pengolahan hilir, dilakukan setelah biji kopi terpisah dari kulit dan kering. Selanjutnya dilakukan proses penyangraian yaitu menggoreng biji kopi dalam wajan tanpa minyak hingga berkurang kadar airnya dan tercium aroma wangi biji kopi siap saji. Kemudian kopi didinginkan sebelum dihaluskan. Setelah kopi menjadi bubuk halus, lalu dikemas dan dijual. Namun beberapa pencinta kopi lebih senang membeli kopi dalam bentuk biji dan proses penghalusan kopi dilakukan sendiri. Dilihat dari proses pengolahannya, buah kopi diolah dalam beberapa tahapan yang panjang semua diproses secara halal. Sekalipun ada pengusaha yang melakukan kecurangan dengan mengurangi kualitas kopi dengan mencampur biji kopi pilihan dengan kopi yang sudah rusak, masih tetap halal dikonsumsi. Tingginya permintaan kopi dan persaingan di pasar, kemungkinan mencampur biji kopi pilihan dan biji kopi rusak sangat mungkin terjadi. Beberapa daerah di Indonesia juga membuat bubuk kopi dengan mencampur biji jagung. Itu pun masih halal untuk dikonsumsi.

Pada brand Salkimah terdapat tagline " $100 \%$ Kopi Robusta" yang memberikan jaminan kepada konsumen bahwa brand Sakinah terbuat dari kopi 
jenis robusta murni dengan kualitas terbaik tanpa campuran biji kopi rusak, kulit kopi maupun campuran biji-bijian yang lain seperti jagung. Selain brand Sakinah yang menjadi jaminan atas kehalalan produk, Tagline " $100 \%$ Kopi Robusta" menguatkannya dengan menyajikan $100 \%$ kopi robusta murni.

Halal cara memperolehnya. Dari sisi produsen, cara memperoleh biji kopi ini melalui transaksi bisnis yang legal dan sesuai aturan perdagangan. Artinya memperolehnya pun didapat secara halal. Jika produsen kopi memperoleh biji dengan cara yang tidak halal seperti mencuri atau melakukan kecurangan dalam pembelian, tentunya usaha kopi Sakinah tidak berjalan dengan lancar.

Dilihat dari sisi konsumen, cara mendapatkan produk kopi Sakinah melalui transaksi bisnis yang syah dan halal. Artinya produk kopi Sakinah dijual harga yang disesuaikan dengan proses produksi dan manajemen perusahaan. Harga jual kopi Sakinah mempertimbangkan berbagai aspek penting yaitu biaya produksi meliputi harga biji kopi pilihan, biaya tenaga kerja, hingga kemasan produk, biaya pemasaran meliputi biaya distribusi, biaya promosi bahkan biaya konsinyasi dan terakhir keuntungan perusahaan yang disisihkan untuk pengembangan perusahaan dan kesejahteraan karyawan.

Penelitian ini juga menyoroti perubahan bentuk pada kemasan produk dari limas dengan bahan dasar kertas Art Paper 220gr yang rumit dalam pengerjaan menjadi lebih praktis dan kekinian. Produk kopi Sakinah berusaha beradaptasi dengan trend produk jenis industri rumah tangga yang lebih simpel dan minimalis yaitu menggunakan kemasan standing pounch paper kraft yang mudah dibuka dan ditutup. Di bawah ini adalah transformasi bentuk kemasan Kopi Leonna menjadi Kopi Sakinah.

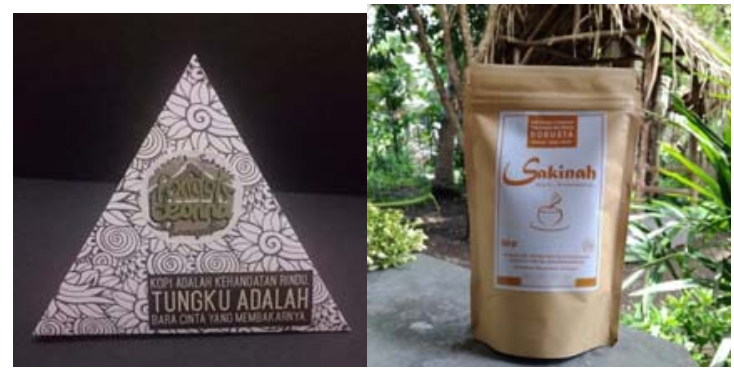

Gambar 5 : Perbandingan Kemasan Kopi Pondok Leonna dan Kopi Sakinah

Perubahan kemasan yang lebih sederhana dan praktis ini juga berdampak pada positioning produk yang lebih Islami. Positioning produk yang dimaksud kemasan baru ini lebih mudah dalam proses pengemasan. Kemasan standing pounch 
paper kraft ini dilapisi dengan alumunium foil di bagian dalamnya yang berfungsi untuk mempertahankan keawetan atau masa kadaluarsa produknya. Kualitas produk juga terjamin kehigienisannya (kebersihan) karena proses pengemasan sangat cepat sehingga meminimalisir terkontaminasi reaksi kimia antara bubuk kopi dan udara. Transformasi bentuk kemasan kopi Sakinah ini bertujuan untuk menguatkan brand pangan Islami di masyarakat.

\section{Simpulan}

Berdasarkan analisis semantik semiotika di atas, penelitian Representasi Brand Islami dalam Produk Kopi Sakinah ini dapat disimpulkan :

Dalam pemilihan kata, pemberian brand Sakinah memberikan kesan bahwa produk kopi memberikan rasa kedamaian, tentram, tenang dan aman. Hal ini dimaksudkan bahwa kedamaian menyiratkan kopi sebagai minuman yang dapat membuat kita tetap terjaga. Dalam sejarahnya, Rasullullah menganjurkan mengkonsumsi kopi sebagai minuman berenergi dapat menambah kekhusyukan dalam menjalankan ibadah di malam hari. Di sisi lain, kata Sakinah telah familiar di masyarakat dan mudah diingat sehingga brand Sakinah mudah tertanam di benak masyarakat Indonesia yang mayoritas beragama Islam sudah mengetahui dan memahami maknanya. Kata Sakinah secara tidak langsung juga menyiratkan makna bahwa kopi tersebut diproses dan diproduksi secara Islami dan halal.

Dalam pembuatan desain tulisan, brand Sakinah mencampurkan dua huruf yaitu huruf hijaiyah "yak" untuk huruf "S" dan huruf latin pada "akinah". Dilihat hari penggunaan huruf saja sudah terlihat bahwa brand Sakinah menjadi identitas Islami pada huruf hijaiyah "yak".

Dalam desain kemasan, brand Sakinah bertransformasi menjadi kemasan yang lebih sederhana dan praktis. Hal ini menyiratkan makna bahwa produk tersebut ingin memberikan kesan yang baik kepada masyarakat bahwa kopi tersebut melalui preoses pengemasan yang praktis dan cepat. Ini sebagai indikator bahwa produsen hendak mengurangi kontaminasi antara bubuk kopi siap saji dengan udara. Kemasan juga dilengkapi dengan alumunium foil di bagian dalam akan melindungi produk lebih aman dari kemasan sebelumnya.

Adapun saran yang dapat peneliti berikan terkait penelitian Representasi Brand Islami dalam Produk Kopi 
Sakinah ini adalah mengingat kultur pasar Indonesia yang mayoritas beragama Islam, hendaknya memberikan nama-nama produk yang bernuansa Islami sehingga brand tersebut akan cepat tertanam di benak masyarakat. Keyakinan masyarakat atas kehalalan produk tersebut dengan cepat direspon hanya dengan membaca brand yang bernuansa Islami. Dengan demikian, akan mempermudah kerja pemasaran dalam mempromosikan produk-produk dengan brand Islami identik dengan produk-produk yang halal.

\section{Daftar Pustaka}

\section{Buku-buku :}

Cravens, David W., 1994, Pemasaran Strategic, Penerbit Airlangga, Jakarta

Manap, Abdul, 2016, Revolusi Manajemen Pemasaran, Mitra Wacana Media, Jakarta

Wibowo, Indiwan Seto Wahyu, 2013,

Semiotika Komunikasi - Aplikasi

Praktis bagi Peneliti dan Skripsi

Komunikasi Edisi 2, Jakarta, Penerbit

Mitra Wacana Media

Yunus, Ulani, Mia Angeline dan Sari Ramadanty, 2017, Advertising \& Branding, Jakarta, Penerbit Edu Pustaka
Pawito, 2007, Penelitian Komunikasi Kualitatif, LKiS Pelangi Aksara, Yogyakarta

Sobur, Alex, 2006, Semiotika Komunikasi, Penerbit Remaja Rosdakarya, Bandung

Kottler, Philip and Gary Amstrong, 1994, Manajemen Pemasaran, Indeks, Jakarta

\section{Jurnal-jurnal :}

Putra, M. Alhafis Wijaya, 2017, Representasi Pakaian Sebagai Identitas Anak Muda (Analisis Semiotika pada Merek Dreambirds Artwear), Penerbit Universitas Islam Indoensia, Yogyakarta

Sumber

https://dspace.uii.ac.id/handle/1234567 $\underline{89 / 4102}$ - diunduh pada tanggal 12 Februari 2019

Dewi, Murti Candra, 2016, Representasi Pakaian Muslimah dalam Iklan (Analisis Semiotika Charles Sanders Peirce pada Iklan Kosmetik Wardah di Tabloid Nova), Universitas Islam Negeri Sunan Kalijaga,

Sumber

http://ejournal.uinsuka.ac.id/isoshum/profetik/article/vie

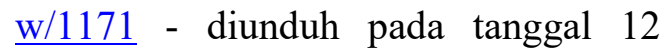
Februari 2019 